\title{
Pancreatic Pseudocyst in Chronic Pancreatitis: Endoscopic and Surgical Treatment
}

\author{
Edoardo Rosso ${ }^{a}$ Nicholas Alexakis ${ }^{a}$ Paula Ghaneh ${ }^{a}$ Martin Lombard ${ }^{b}$ \\ Howard L. Smart $^{\text {b }}$ Johnathan Evans ${ }^{c}$ John P. Neoptolemos ${ }^{a}$ \\ Departments of a Surgery, ${ }^{b}$ Gastroenterology and ${ }^{c}$ Radiology, Royal Liverpool University Hospital, Liverpool, UK
}

\section{Key Words}

Endoscopy · Pancreatitis · Pseudocyst, pancreatic · Surgery

\section{Introduction}

The incidence and prevalence of chronic pancreatitis appear to be increasing [1-4]. Pancreatic pseudocyst is a common complication of chronic as well as acute pancreatitis that is unrelated to the underlying aetiology. Advances in radiological techniques have in part led to an increase in the diagnosis of pseudocyst and better characterization of associated complications. There is now a better understanding of the natural history of pseudocysts in relation to the underlying disease. The introduction of new treatment modalities has also increased the options for surgical management. Thus with better knowledge of the disease and with technical advances the indications, timing and methods to treat pancreatic pseudocysts have undergone a marked evolutionary change.

\section{Definition}

A pancreatic pseudocyst is a localised collection of pancreatic-enzyme-rich fluid, originating in or adjacent to the pancreas and enclosed in a wall of granulation and/or fibrous tissue lacking an epithelial lining [5]. The principle mechanism leading to pseudocyst formation is believed to involve disruption of the main pancreatic duct and/or peripheral ductules causing leakage and activation of pancreatic enzymes, which in turn leads to localised autodigestion and necrosis of pancreatic parenchyma. This evokes an inflammatory response with the formation of a distinct pseudocyst wall composed of granulation tissue and blood vessels that organizes with more connective tissue and fibrosis [6-11].

On-table pancreatography [12] and endoscopic retrograde cholangiopancreatography (ERCP) have demonstrated a communication between the pseudocyst and the pancreatic ductal system in up to $80 \%$ of the patients [13, 14], and peripheral or main pancreatic duct disruption is known to be an early event in acute pancreatitis [15]. Rarely disruption of a retention cyst [16] or trauma that disrupts the pancreatic ductal system may also lead to a pseudocyst [17-19].

\section{KARGER \\ Fax +4161306 1234 \\ E-Mail karger@karger.ch \\ www.karger.com \\ (C) 2003 S. Karger AG, Basel \\ 0253-4886/03/0205-0397\$19.50/0 \\ Accessible online at: \\ www. karger.com/dsu}

Prof. J.P. Neoptolemos, MA, MB, BChir, MD, FCRS

Department of Surgery, University of Liverpool

UCD Building, Royal Liverpool University Hospital

Daulby Street, Liverpool, L69 3GA (UK)

Tel. +44 151706 4175, Fax +44 151706 5826, E-Mail j.p.neoptolemos@liv.ac.uk 
Pour et al. [20] showed that the histological appearance of the pseudocyst wall was independent of the cause with no discernible differences in the structure of the wall between alcoholic, gallstone and idiopathic pancreatitis. The histological findings are identical for acute pseudocysts and chronic pseudocysts [21]. The pseudocyst wall is composed of granulation and fibrous tissue without an epithelial wall in contrast to retention cysts that are lined by epithelial tissue. The wall of acute pseudocysts can be divided into four zones. The inner zone is narrow and contains haemosiderin pigment and loose connective tissue. The second zone is made up of inflammatory and capillary-rich fibrous tissue. The third area is composed of hyalinized connective tissue that is depleted of cells and the outer zone consists of capillary-rich fibrous stroma. The structure and the thickness of the enveloping fibrous capsule appear to be time dependent. Older cysts have thicker walls with increased collagen, fibronectin, and smooth muscle content. Warshaw and Rattner [22] have proposed the evaluation of the isoamylase content of pseudocysts as a predictor of pseudocyst wall maturation.

\section{Incidence}

Pseudocysts account for about two thirds of all pancreatic cystic lesions and complicate chronic pancreatitis in $20-40 \%$ of patients [23-25]. In acute pancreatitis pseudocysts arise in 10-20\% of patients [26-29]. In one of our series of 102 consecutive patients with acute pancreatitis all of whom had abdominal computed tomography (CT) within $72 \mathrm{~h}$ of admission, repeated at 1 and 6 weeks, 14 (14\%) developed a pseudocyst, that was present at 6 weeks [30].

\section{Diagnosis}

The commonest symptom is abdominal pain (76$94 \%)$, early satiety, nausea and vomiting (50\%) and weight loss (20-51\%). Physical examination may reveal upper abdominal tenderness and epigastric fullness rather than a mass (60\%). Obstructive jaundice (up to $20 \%$ ) and duodenal obstruction may result from the mass effect on adjacent viscera [31].

The key investigation is high-quality dual-phase CT performed with a specific pancreas imaging protocol but ancillary investigations include endoscopic ultrasonography (EUS), ERCP or magnetic resonance cholangiopan- creatography and transabdominal ultrasonography. It has been argued that the risks associated with ERCP from bacterial colonization of the pseudocyst and post-procedural acute pancreatitis outweigh the potential benefits of anatomical delineation $[32,33]$. Yet the information obtained by ERCP can change the operative plan in more than $50 \%$ of patients showing previously unknown biliary obstruction or pancreatic duct strictures [14, 34, 35]. Much the same information may be provided by EUS and it seems likely that magnetic resonance cholangiopancreatography will largely supplant ERCP for diagnostic uses leaving ERCP the privilege of intervention. There is general consensus that ERCP in patients with a pancreatic pseudocyst should be performed under broad-spectrum antibiotic cover whether for diagnostic or therapeutic reasons.

\section{Differential Diagnosis}

The differential diagnosis includes acute peri-pancreatic fluid collections, pancreatic necrosis, cystic pancreatic tumour $(<1 \%$ of all pancreatic neoplasms, but approximately $10 \%$ of pancreatic cysts), hydatid cyst and congenital pancreatic cysts [36]. Pancreatic lesions, notably multiple cysts in conjunction with a neuroendocrine tumour, are a common feature of von Hippel-Lindau's disease. The differentiation of a pancreatic cystic tumour from a pseudocyst is often difficult. A key feature is the overall clinical presentation (notably age, history of excess alcohol consumption, history of pancreatitis, gender and location of the pseudocyst) and radiological appearance. Features that tend to favour a cystic neoplasm are an absence of a history of alcohol abuse, being relatively young, being female, location of the pseudocyst in the tail of the pancreas, the presence of central or peripheral calcification and the presence of septae or loculations. Some authors have proposed percutaneous aspiration and analysis of cystic fluid for viscosity, carcinoembryonic antigen (CEA), CA-125, and cytology. CA-125 and CEA levels are lower in pseudocysts and high in neoplastic cysts. CA 19-9 is non-discriminatory and may be even higher in pseudocysts than in neoplastic cysts. An elevated serum CA 19-9 is also common in acute and chronic pancreatitis. Amylase levels are high in pseudocysts and generally low in cystic tumours. Cytological analysis of cysts may be useful for mucinous cysts but is of limited value for serous cystoadenoma. Even intraoperative biopsy of the cyst wall for frozen section histopathology is unreliable (incorrect in $20 \%$ or more of cases). Furthermore, there is also the

\footnotetext{
$\overline{398} \quad \overline{\text { Dig Surg 2003;20:397-406 }}$
}

Rosso/Alexakis/Ghaneh/Lombard/Smart/ Evans/Neoptolemos 
potential risk of tumour seeding [7, 37, 38]. Finally it is important to remember that chronic pancreatitis is a significant risk factor for pancreatic cancer [39-41], and the two conditions may coexist in $5-10 \%$ of cases.

\section{Natural History of Pancreatic Pseudocysts}

A pancreatic pseudocyst may regress spontaneously (table 1); persist with or without symptoms, or progress to produce complications [42, 43]. Many studies have been undertaken in an attempt to identify predictive factors in the outcome of pancreatic pseudocysts in order to facilitate management. Accurate interpretation of these studies is usually difficult because they frequently include a mix of cases with acute and chronic pancreatitis. In acute pancreatitis most acute fluid collections spontaneously resolve [5] although some 10-20\% will evolve into pseudocysts $[17,27,42]$. Out of the 14 pseudocysts identified by serial CT in our series of 102 consecutive patients, only 5 (36\%) became clinically significant [30]. The pseudocyst size indices (maximum antero-posterior $\times$ maximum transverse diameters) of the pseudocysts that were clinically apparent were significantly greater than those which were not apparent $(\mathrm{p}<0.001)$ and only those pseudocysts with a size index greater than or equal to $15 \mathrm{~cm}^{2}$ required treatment [30].

In 1981 Crass and Lawrence [17] observed that whilst some acute pancreatic pseudocysts resolved without operation over a period of 4-6 weeks, pancreatic pseudocysts that were associated with chronic pancreatitis rarely underwent spontaneous resolution. Regression rates for asymptomatic chronic pancreatic pseudocysts vary between 9 and 31\% [44], with the lower figure being closer to our experience. In older series, regression rates of up to $57-67 \%$ were reported, but the criteria for distinguishing acute from chronic pancreatitis were far less stringent for inclusion.

Warshaw and Rattner [22] investigated 42 consecutive patients with pseudocysts treated over 5 years: 31 were due to alcohol, 2 were due to gallstones and 9 had idiopathic pancreatitis. Of these 42 patients, 20 had chronic pancreatitis, 14 had acute and 8 had acute on chronic pancreatitis. Spontaneous pseudocyst resolution occurred in $3(7 \%)$ patients, all of whom had recent acute idiopathic pancreatitis and pancreatograms that showed the main pancreatic duct freely communicating with the pseudocyst. Factors associated with failure to resolve were chronic pancreatitis, persistence $>6$ weeks and a thick wall on imaging [22].

Pseudocyst in Chronic Pancreatitis
Table 1. Factors associated with pseudocyst resolution

\author{
Acute pancreatitis \\ Small pseudocyst size \\ Intrapancreatic pseudocyst \\ Pseudocyst of the head of the pancreas \\ Persistence $<6$ weeks \\ Thin pseudocyst wall
}

Gouyon et al. [43] followed up to 90 patients with alcohol-related chronic pancreatitis complicated by pseudocyst over 10 years using serial CT and/or ultrasonography to monitor the evolution of the pseudocyst. They were divided in two groups based on the pattern of evolution and the need for intervention. The conservative group comprised 25 patients with pseudocysts that regressed spontaneously and 20 patients with pseudocysts that persisted without any symptoms (group I, $\mathrm{n}=45$ ). The other group comprised patients with persisting symptoms or complications, requiring either surgical or non-surgical intervention (group II, $\mathrm{n}=45$ ). The evolution of pseudocysts was monitored by CT or abdominal ultrasonography. On univariate analysis, location of the pseudocyst in the head of the pancreas and intrapancreatic development were more frequent in group I than in group II (78 vs. $55 \%, \mathrm{p}<0.02 ; 89$ vs. $60 \%, \mathrm{p}<0.001$, respectively). The diameter of pseudocysts was smaller in group I (median: $25 \mathrm{~mm}$, range $10-110 \mathrm{~mm}$ ) than in group II (median: $40 \mathrm{~mm}$, range $10-120 \mathrm{~mm}, \mathrm{p}<0.0001$ ). No significant differences were found between any clinical or biochemical parameters. Multivariate analysis showed that the intrapancreatic development of pseudocysts and a diameter $<4 \mathrm{~cm}$ were the only independent factors associated with spontaneous resolution. These factors accounted for $20 \%$ of the total variance. It was concluded that pseudocysts $>4 \mathrm{~cm}$ in diameter and an extrapancreatic position were independent predictive factors of persisting symptoms and/or complications in patients with pseudocysts and alcohol-related chronic pancreatitis. Indeed most studies suggest that size is a predictive factor for pseudocyst resolution, and Nguyen et al. [45] and Yeo et al. [46] have demonstrated that there is no definable threshold.

The risk of life-threatening complications is around $10 \%$ and includes the following [16, 27, 28, 42, 47-50]: (1) biliary duct compression/stenosis; (2) duodenal compression/stenosis; (3) rupture; (4) compression or oblitera-

Dig Surg 2003;20:397-406 
Table 2. Nealon and Walser [52]: ERCP classification of pseudocysts with regard to the pancreatic ductal anatomy

\section{Acute pancreatitis}

Type I normal duct/no communication

Type II normal duct/with communication

Type III normal duct with stricture/no communication

Type IV normal duct with stricture/with communication

Type V normal duct/complete obstruction

\section{Chronic pancreatitis}

Type VI abnormal duct/no communication

Type VII abnormal duct/with communication

tion of one or more of the hepatic portal, superior mesenteric and splenic veins with the formation of collateral veins (this in turns will result in gastric varices in the first instance and later oesophageal varices); (5) pseudoaneurysm; (6) haemorrhage; (7) pancreatic ascites due to a communicating pseudocyst-peritoneal fistula, and (8) infection.

\section{Classification}

There have been many systems of pseudocyst classification (e.g. D'Egidio and Schein [51]) that have not held up as the characteristics and the natural history of the disease have become better understood. Nealon and Walser [52] have proposed a simple ERCP classification of pancreatic ductal anatomy in pancreatic pseudocysts (table 2). The following are key features that we believe must be known for optimum clinical management [53-55]. (1) The underlying cause of pancreatitis and whether there has been a history of acute pancreatitis or whether there is underlying chronic pancreatitis. (2) The duration of time that it has been present. (3) The diameter of the pseudocyst. (4) Any symptoms related to the pseudocyst and whether it is regressing, remaining stable in size or whether it is enlarging. (5) The location whether within the pancreas (head, body, or tail) or adjacent to the pancreas. (6) Whether it is distant from the pancreas such as the mediastinum, liver, and the pelvis. (7) Single or multiple pseudocysts. (8) Complex pseudocyst associated with major complications such as compression or obliteration of the hepatic portal, superior mesenteric and splenic veins with the formation of collateral veins, biliary, gastric duodenal compression, pancreato-pleural fistula and pancreatic ascites. (9) The state of the main pancreatic
Table 3. Indications for intervention

Complicated pseudocyst, notably of one or more of the following

Causing compression of major veins (either symptomatic or on CT imaging)

Causing symptomatic compression of the stomach or duodenum

Causing compression of the main bile duct (as evident from symptoms or elevated liver function tests)

Associated with pancreatic ascites or a pancreato-pleural fistula

Infection

Haemorrhage

Symptomatic pseudocyst

Persistent or recurrent feeling of fullness, early satiety, nausea or vomiting despite optimum medical therapy

Severe abdominal and/or back pain not responding to optimum medical management

Asymptomatic pseudocyst, with the following relative risk factors

Pseudocyst $>4 \mathrm{~cm}$, present for $>6$ weeks with no evidence or regression or enlarging

Pseudocyst has a thick capsule

Background of chronic pancreatitis

No communication between the main pancreatic duct and the pseudocyst on direct ductal imaging

Pseudocyst lying outside of the pancreas

Main pancreatic duct anomaly including stones and strictures

Suspicion that the pseudocyst is actually a neoplastic cyst or is associated with a neoplastic lesion (fear of cancer - need for resection)

Patients with asymptomatic pseudocysts are carefully monitored by radiology for an increase in size and the development of any associated complications; serial tumour markers are also performed although it should again be noted that CA 19-9, probably the best serum marker for pancreatic cancer, is often elevated in patients with chronic pancreatitis

and intrapancreatic bile ducts. (10) Pseudocyst in association with pancreatic cancer (in contradistinction to a neoplastic pancreatic cyst).

\section{Criteria for Intervention in Liverpool}

On the basis of our experience and with support of the literature we have developed a useful guide to help in judging the timing for intervention when we are facing a pancreatic pseudocyst. Our views are to some extent influenced by the very aggressive chronic pancreatitis observed in the Liverpool region with a very high frequency of calcifying chronic pancreatitis and a high incidence of vascular complications. With this caveat, the indications for intervention are listed in table 3 . 


\section{Endoscopic Management of Pancreatic Pseudocysts}

The first successfully completed transmural drainage procedures were described as in an abstract by Khawaja and Goldman [56] in 1983 and then 1 year later in 4 patients by Kozarek et al. [57]. Initially there was a rather low success rate and a relatively high morbidity, but with increased experience and development of the endoscopic techniques there are now good results reported in two thirds or more of the patients with a low mortality and relatively few complications.

\section{Prerequisites for the Endoscopic Treatment of}

Pancreatic Pseudocysts

A number of essential requirements are necessary before endoscopic drainage is undertaken that may vary according to the endoscopic technique adopted.

Transmural drainage through the stomach or the duodenum requires the following conditions [58-65]: (1) the stomach or duodenal wall must share a common wall with the pseudocyst; (2) the distance between the pseudocyst and the gastric wall must be $<1 \mathrm{~cm}$ on preoperative investigations; (3) there must be a clear impression of the wall of the stomach or duodenum at the endoscopy; (4) the absence of varices; (5) it is imperative that the cyst structure is not a neoplasm or a pseudoaneurysm by aspiration of the cystic content.

Transpapillary drainage requires a communication between the main pancreatic ductal system and the pseudocyst. This approach may still be possible in the face of proximal duct obstruction by stones or stricture or complete disruption of the pancreatic duct. It is clear from the aforementioned that most pseudocysts located in the pancreatic tail are not suitable for endoscopic drainage.

\section{Techniques for the Endoscopic Treatment of \\ Pancreatic Pseudocysts}

Several methods have been described for performance of endoscopic pseudocystenterostomy, but no randomised studies comparing the different techniques have been performed so that there is no standard approach. The key issues concern the localization of the puncture site, maintaining access to the cyst cavity, choice of the correct size of the endoprosthesis and the management of an infected or complex pseudocyst.

The requirements for a successful transmural drainage procedure include endoscopic visualization of the most prominent point of bulging into the gastric or duodenal lumen, puncture of the pseudocyst with a pre-cut knife, cannulation of the opening with a guidewire followed by sphincterotomy to enlarge the communication, opacification of the pseudocyst cavity with contrast and finally placement of a pigtail endoprosthesis (or prostheses) of the correct size (7-12 F). Many endoscopists also now use EUS to identify the site of puncture and to avoid occasional puncture of a vessels or to perform one-step EUSguided pseudocyst drainage [59, 62].

Transpapillary pseudocyst drainage is technically more demanding than transmural drainage. At the ERCP the guidewire is advanced into the main pancreatic duct and then into the pseudocyst cavity. A pancreatic duct sphincterotomy may be necessary and the stent is placed in situ. Unfortunately it is usually only possible to place a stent that is of rather small calibre, so it is important that the pseudocyst fluid should be clear otherwise the stent will rapidly become occluded by viscid fluid or thick necrotic debris. If a stricture of the main pancreatic duct is found, dilatation should be attempted before stent placement [66-69].

\section{Results of Endoscopic Treatment of Pancreatic Pseudocysts}

The results for endoscopic drainage are generally good, with a technical success rate between 80 and $90 \%$ for transmural pseudocystgastrostomy and pseudocystoduodenostomy and almost $85 \%$ for transpapillary methods (table 4). The long-term resolution rate for both methods is of the order of $65-75 \%$ with a recurrences rate of up to $30 \%$ of patients and stent migration. These complications occur in up to $30 \%$ of patients and may require emergency surgery; thus an experienced pancreatic surgical team and expert interventional radiologist should always be available at short notice when these techniques are being undertaken. The published mortality rate is now less than $1 \%$ but appears to be biased in favour of experienced endoscopic teams and highly selected cases [56-59, 62-83].

\section{Surgical Treatment}

The treatment of pancreatic pseudocysts has traditionally been surgical. The advantages are that associated underlying pathology may be dealt with and drainage of the pseudocyst itself may be regarded as definitive. The surgeon may also navigate around varices in occlusive venous disease considered a major contraindication for radiological or endoscopic intervention [84]. Jedlicka [85] performed the first pseudocystgastrostomy in 1921. 
Table 4. Results of the endoscopic treatment of pancreatic pseudocysts

\begin{tabular}{|c|c|c|c|c|c|c|c|c|c|}
\hline References & Year & Patients & $\begin{array}{l}\text { Trans- } \\
\text { mural }\end{array}$ & $\begin{array}{l}\text { Trans- } \\
\text { papillary }\end{array}$ & $\begin{array}{l}\text { Trans- } \\
\text { mural and } \\
\text { trans- } \\
\text { papillary }\end{array}$ & Morbidity & $\begin{array}{l}\text { Failed or } \\
\text { needed } \\
\text { surgery }\end{array}$ & Mortality & $\begin{array}{l}\text { Recur- } \\
\text { rence }\end{array}$ \\
\hline Kozarek et al. [57] & 1985 & 4 & 4 & 0 & 0 & $1(25 \%)$ & $2(50 \%)$ & $1(25 \%)$ & 0 \\
\hline Cremer et al. [73] & 1989 & 33 & 33 & 0 & 0 & $3(9 \%)$ & $5(15 \%)$ & 0 & $4(12 \%)$ \\
\hline Sahel et al. [63] & 1991 & 37 & 37 & 0 & 0 & $5(14 \%)$ & $5(14 \%)$ & 0 & $2(5 \%)$ \\
\hline Kozarek et al. [69] & 1991 & 14 & 0 & 14 & 0 & $3(21 \%)$ & $3(21 \%)$ & 0 & $2(21 \%)$ \\
\hline Bejamin et al. [72] & 1993 & 26 & 26 & 0 & 0 & $4(15 \%)$ & $7(27 \%)$ & 0 & $4(15 \%)$ \\
\hline Funnel et al. [76] & 1994 & 5 & 5 & 0 & 0 & 0 & 0 & 0 & 0 \\
\hline Deviere et al. [74] & 1995 & 12 & 5 & 3 & 4 & $2(13 \%)$ & $2(13 \%)$ & 0 & 0 \\
\hline Barthet et al. [26] & 1995 & 30 & 0 & 20 & 10 & $4(13 \%)$ & $7(23 \%)$ & 0 & $3(10 \%)$ \\
\hline Binmoeller et al. [67] & 1995 & 53 & 16 & 33 & 4 & $6(11 \%)$ & $6(11 \%)$ & 0 & $11(22 \%)$ \\
\hline Smits et al. [64] & 1995 & 37 & 18 & 12 & 7 & $7(19 \%)$ & $13(35 \%)$ & 0 & $3(8 \%)$ \\
\hline Vitale et al. [49] & 1999 & 36 & 27 & 9 & 0 & $1(2.8 \%)$ & $5(13.9 \%)$ & 0 & $5(14 \%)$ \\
\hline White et al. [83] & 2000 & 20 & 20 & 0 & 0 & $2(10 \%)$ & $2(10 \%)$ & 0 & 0 \\
\hline Libera et al. [79] & 2000 & 25 & 25 & 0 & 0 & $6(28 \%)$ & $4(16 \%)$ & 0 & $1(4 \%)$ \\
\hline Giovannini et al. [77] & 2001 & 15 & 10 & 5 & 0 & $1(6.6 \%)$ & 0 & 0 & $1(6.6 \%)$ \\
\hline Norton et al. [80] & 2001 & 17 & 14 & 0 & 0 & $1(5.9 \%)$ & $3(17.6 \%)$ & 0 & $1(7.1 \%)$ \\
\hline Sharma et al. [81] & 2002 & 38 & 33 & 5 & 0 & $5(13 \%)$ & $1(3 \%)$ & 0 & $7(16 \%)$ \\
\hline Baron et al. [70] & 2002 & 64 & 54 & 10 & - & $11(17 \%)$ & - & 0 & $7(12 \%)$ \\
\hline Total & & 466 & $\begin{array}{c}327 / 466 \\
(70.2 \%)\end{array}$ & $\begin{array}{l}111 / 466 \\
(23.8 \%)\end{array}$ & $\begin{array}{r}25 / 466 \\
(5.4 \%)\end{array}$ & $\begin{array}{l}62 \\
(13.3 \%)\end{array}$ & $\begin{array}{l}72 \\
(15.4 \%)\end{array}$ & $\begin{array}{l}1 \\
(0.2 \%)\end{array}$ & $\begin{array}{l}50 \\
(10.7 \%)\end{array}$ \\
\hline
\end{tabular}

Since then many reports have been published with excellent operative results, low morbidity, mortality and recurrences rates. Despite the recent introduction of minimally invasive techniques for dealing with pancreatic pseudocysts, there remains a clear preference for the open surgical treatment of established pseudocysts. With this viewpoint the indications for surgical treatment are as follows [22, 25, 28, 86-93]: (1) contraindication or failure of endoscopic and radiological methods; (2) pseudocysts with complex or multiple main pancreatic duct strictures; (3) associated complex pathology such as an inflammatory mass in the head of the pancreas; (4) pseudocysts with a main bile duct stricture; (5) venous occlusive disease; (6) multiple pseudocysts; (7) most pseudocysts of the pancreatic tail; (8) haemorrhage not adequately controlled by angiographic transcatheter embolization, and (9) suspicion of a neoplastic cyst.

Endoscopic techniques are available for treating biliary strictures, but long-term success is unlikely in the presence of severe underlying chronic pancreatitis in the head of the pancreas. Radiological techniques are also available to relieve partial occlusion of the porto-splenic-mesenteric system but are probably best reserved as an initial procedure prior to definitive surgery. For these reasons we believe that the criteria we use in Liverpool (outlined above) reflect the optimum surgical approach.

The three main surgical operations available for the treatment of pancreatic pseudocysts are (a) internal drainage, (b) pancreatic resections and (c) external drainage.

\section{Internal Drainage}

In 1921 Jedlicka [85] sutured the posterior wall of the stomach to a pancreatic pseudocyst, performing the first reported pseudocystgastrostomy. Since then two other types of anastomosis have been introduced, the pseudocystduodenostomy and the pseudocystjejunostomy. The classical approach requires a midline or sub-costal incision, exposure of the lesser sac, biopsy of the pseudocyst wall, aspiration of pseudocyst fluid, breakdown of any multilocules and finally anastomosis of the pseudocyst with the stomach, duodenum or jejunum according to the preference of the surgeon and anatomical situation. In patients with multiple pseudocysts, multiple anastomoses may be fashioned. Whilst the lesser sac approach is preferable, the anastomosis in some cases may be more safely performed using an approach through the transverse mesocolon, especially on the left (space of Riolan). It is important to underline that in all cases a non-epithelial- 
Table 5. Results of internal drainage

\begin{tabular}{|c|c|c|c|c|c|c|c|}
\hline Author & Year & Type of operation & Patients & Success rate & Morbidity & Mortality & Recurrence \\
\hline \multirow[t]{3}{*}{ Sankaran and Walt [96] } & 1975 & pseudocystduodenostomy & 8 & $8(100 \%)$ & NR & 0 & 0 \\
\hline & & pseudocystgastrostomy & 25 & $23(92 \%)$ & & $2(8 \%)$ & $2(8 \%)$ \\
\hline & & pseudocystjejunostomy & 23 & $19(83 \%)$ & & $1(4 \%)$ & $4(17 \%)$ \\
\hline Altimari et al. [94] & 1986 & pseudocystduodenostomy & 11 & $11(100 \%)$ & $4(36 \%)$ & 0 & 0 \\
\hline \multirow[t]{3}{*}{ Nealon et al. [14] } & 1989 & pseudocystduodenostomy & 1 & $1(100 \%)$ & $3(9 \%)$ & 0 & NR \\
\hline & & pseudocystgastrostomy & 11 & $11(100 \%)$ & & 0 & NR \\
\hline & & pseudocystjejunostomy & 22 & $22(100 \%)$ & & 0 & NR \\
\hline \multirow[t]{2}{*}{ Newell et al. [95] } & 1990 & pseudocystgastrostomy & 39 & $35(90 \%)$ & $13(13 \%)$ & $2(5 \%)$ & $4(10 \%)$ \\
\hline & & pseudocystjejunostomy & 59 & $55(93 \%)$ & & $2(3 \%)$ & $4(7 \%)$ \\
\hline \multirow[t]{3}{*}{ Vitas and Sarr [50] } & 1992 & pseudocystduodenostomy & 2 & $2(100 \%)$ & $5(36 \%)$ & 0 & 0 \\
\hline & & pseudocystgastrostomy & 8 & $7(90 \%)$ & & 0 & $1(10 \%)$ \\
\hline & & pseudocystjejunostomy & 4 & $4(100 \%)$ & & 0 & 0 \\
\hline \multirow[t]{2}{*}{ Spivack et al. [97] } & 1998 & pseudocystgastrostomy & 14 & $13(93 \%)$ & $5(24 \%)$ & 0 & NR \\
\hline & & pseudocystjejunostomy & 7 & $6(86 \%)$ & & 0 & NR \\
\hline \multirow[t]{3}{*}{ Heider et al. [29] } & 1999 & pseudocystduodenostomy & 4 & $4(100 \%)$ & $(21 \%)^{1}$ & 0 & 0 \\
\hline & & pseudocystgastrostomy & 10 & $7(70 \%)$ & & 0 & $3(30 \%)$ \\
\hline & & pseudocystjejunostomy & 28 & $24(86 \%)$ & & 0 & $4(14 \%)$ \\
\hline \multirow[t]{6}{*}{ Usatoff et al. [25] } & 2000 & pseudocystduodenostomy & 2 & $2(100 \%)$ & $(28 \%)^{1}$ & 0 & 0 \\
\hline & & pseudocystjejunostomy & 43 & $42(98 \%)$ & & $1(2 \%)$ & $1(2 \%)$ \\
\hline & & & & & $\begin{array}{l}\text { total } \\
\text { morbidity }\end{array}$ & & \\
\hline & total & pseudocystduodenostomy & 28 & $28(100 \%)$ & $25 / 157(16 \%)^{2}$ & $8 / 321(2.5 \%)$ & 0 \\
\hline & total & pseudocystgastrostomy & 107 & $96(90 \%)$ & & & $10 / 82(12 \%)^{3}$ \\
\hline & total & pseudocystjejunostomy & 186 & $172(92 \%)$ & & & $13 / 153(8.5 \%)^{3}$ \\
\hline \multicolumn{8}{|c|}{ NR = Not reported. } \\
\hline \multicolumn{8}{|c|}{1 Including pancreatic resections and external drainage. } \\
\hline \multicolumn{8}{|c|}{ Result obtained considering $[14,50,94,95]$ only. } \\
\hline \multicolumn{8}{|c|}{ Result obtained considering $[25,29,50,94-96]$ only. } \\
\hline
\end{tabular}

lined structure (pseudocyst) is sutured to epithelial tissue (stomach or small intestine). Cooperman [88] showed that these anastomoses will soon stricture and finally obliterate with the disappearance of the pseudocyst.

Pseudocystduodenostomy is indicated for small pseudocysts $(<4 \mathrm{~cm})$ in the head of the pancreas and uncinate process that impinge on the duodenal wall. The results of this operation have been consistently very good (table 5 ) with a reported surgical failure rate of up to $5 \%$ and a low morbidity and mortality, but for anatomical and clinical reasons only a few patients are suitable for this operation [14, 25, 29, 50, 94-97].

Controversy continues to animate discussion as to whether pseudocystgastrostomy should be preferred to pseudocystjejunostomy. There is no definitive answer from the review of the literature and in particular there is a lack of randomised controlled clinical trials. The propo- nents of pseudocystgastrostomy argue that it is a relatively simple and quick procedure with a low infection rate [95]. On the other hand, there are a number of drawbacks. These include the risk of post-operative life-treating upper gastrointestinal bleeding (from the anastomosis between the pseudocyst and the posterior wall of the stomach, erosion of the pseudocyst wall by gastric acid, or development and rupture of a pseudoaneurysm), and from the problems encountered in draining pseudocysts not adherent to the stomach or contained outside of the lesser sac [87]. Cooperman [88] argued that the risk of reflux contamination of the cavity by gastric contents is small because peristalsis governs emptying of the stomach and the union between the stomach and pseudocyst is short-lived.

The results of major series of pseudocystgastrostomy and pseudocystjejunostomy are shown in table 4 . The use 
of pseudocystjejunostomy seems to be more popular and perhaps has somewhat better results than pseudocystgastrostomy. Our approach along with most leading specialist pancreas centres is always to use a Roux-en-Y pseudocystjejunostomy. Indeed the same loop may be used to drain an obstructed bile duct and/or a pancreatic duct dilatation via pancreaticojejunostomy [98, 99]. Traditionally only non-infected pseudocysts were suitable for internal drainage, although recently Boerna et al. [100] reported good results with this technique even for the treatment of infected pancreatic pseudocysts.

\section{Resection}

Pancreatic resection consists of partial left pancreatectomy preferably preserving the spleen if possible, rightsided partial pancreatectomy (pylorus-preserving pancreatoduodenectomy, Beger's operation or Frey's procedure) [47, 101-103]. Resections are more frequently done for multiple small pseudocysts, biliary and pancreatic duct obstruction, duodenal obstruction, haemorrhage and underlying extensive chronic pancreatitis with severe symptoms.

\section{External Drainage}

External drainage is used mainly for infected pseudocysts and thus hardly ever applies to patients with chronic pancreatitis unless they have developed a superimposed attack of necrotizing pancreatitis. In fact this situation is quite unusual and most reports mistakenly refer to the external drainage of sterile or infected necrosis (with a liquid component) from acute pancreatitis per se or the usually unnecessary drainage of acute fluid collections.

\section{Conclusions}

A pancreatic pseudocyst associated with chronic pancreatitis represents one aspect of a complex disease process with multiple clinical presentations. There are widely differing degrees of morbidity that range from simple asymptomatic pseudocyst that can resolve without treatment, to multiple pseudocysts associated with biliary and pancreatic duct obstruction that necessitate surgery. The management of pseudocysts that complicate acute pancreatitis is quite different from those that affect chronic pancreatitis, in that once the attack has resolved the background pathology essentially returns to normal, that is to say a normal pancreatic parenchyma with little or no associated damage to adjacent viscera or vessels. Thus the distinction between acute and chronic pseudocysts is paramount for a successful treatment strategy. Endoscopic and surgical treatments of pancreatic pseudocysts have a high success rate in expert hands, although there are still surprisingly few studies that can be directly compared.

An integrated multi-disciplinary team approach that involves pancreatic specialist surgeons, gastroenterologists and interventional radiologists is essential to identify the best treatment for each individual patient. Once internal drainage has been chosen our preference is for pseudocystjejunostomy as this has many advantages in expert hands.

\section{References}

1 Dite P, Stary K, Precechtelova M, Dolin J, Lata $\mathrm{J}$, Zboril V: Incidence of chronic pancreatitis in the Czech Republic. Eur J Gastroenterol Hepatol 2001;13:748-750.

2 Secknus R, Mossner J: Changes in incidence and prevalence of acute and chronic pancreatitis in Germany. Chirurg 2000;71:249-252.

3 Andersen BN, Pedersen NT, Scheel J, Wornig $\mathrm{H}$ : Incidence of alcoholic chronic pancreatitis in Copenhagen. Scand J Gastroenterol 1982; 17:247-252.

4 Takebe T, Murashima J, Suga T, Satoh M: A report on the epidemiology and the clinical features of the patients with chronic pancreatitis in Hokkaido District. Hokkaido Igaku Zasshi 1987;62:461-468
5 Bradley E and Members of the Atlanta International Symposium: A clinically based classification system for acute pancreatitis. Arch Surg 1993; 128:586-590.

6 Göke B, Meyer T, Loth H, Adler G, Arnold R: Characterization of phospholipase A2 activity in aspirates of human pancreatic pseudocysts after isolation by reverse-phase high-performance liquid chromatography. Klin Wochenschr 1989;67:131-135.

7 Lasson A, Genell S, Nilsson A: Proteolytic activity in pancreatic pseudocyst fluid. Int $\mathbf{J}$ Pancreatol 1994;15:201-208.

8 Lasson A, Goransson J, Ohlsson K: Pancreatic pseudocyst fluid - A mixture of plasma proteins and pancreatic juice possessing a high proteolytic activity. Scand J Clin Lab Invest 1989;49:403-412.
9 Neoptolemos JP: Endoscopic retrograde cholangio-pancreatography in necrotizing pancreatitis; in Bradley EL (ed): Acute Pancreatitis: Diagnosis and Therapy. New York, Raven, 1993, pp 69-76.

10 Pitchumoni CS, Agarwal N: Pancreatic pseudocysts. When and how drainage should be performed? Gastroenterol Clin North Am 1999; 28:615-639.

11 Richter HM: Natural history of pancreatic pseudocysts; in Howard J, et al (eds): Surgical Diseases of the Pancreas. Baltimore, Williams \& Wilkins, 1998, pp 417-421.

12 Desa LA, Williamson RCN: On-table pancreatography: Importance in planning operative strategy. Br J Surg 1990;77:1145-1150. 
13 D'Egidio A, Schein H: Percutaneous drainage of pancreatic pseudocysts: A prospective study. World J Surg 1991;16:141.

14 Nealon WH, Townsend CM, Thompson JC: Preoperative endoscopic retrograde cholangiopancreatography (ERCP) in patients with pancreatic pseudocysts associated with resolving acute pancreatitis and chronic pancreatitis. Ann Surg 1989;209:532-537.

15 Neoptolemos JP, London NJM, Carr-Locke DL: Assessment of main pancreatic duct integrity by endoscopic retrograde pancreatography in patients with acute pancreatitis. Br J Surg 1993;80:94-99.

16 Huizinga WK, Baker LW: Treatment of persistent and complicated pancreatic pseudocysts. J R Coll Surg Endinb 1992;37:373-376.

17 Crass RA, Lawrence WW: Acute and chronic pancreatic pseudocysts are different. Am J Surg 1981;142:660-663.

18 McConnel DB, Gregory JR, Saski TM, Vetto RM: Pancreatic pseudocyst. Am J Surg 1982; 143:599-601.

19 Warren KW, Hofman G: Surgery of the pancreas. Surg Clin North Am 1976;56:615.

20 Pour PM, Thompson JS, Baxter BT: Pathology of pancreatic pseudocysts; in Bradley EL III (ed): Acute Pancreatitis. New York, Raven, 1994, pp 181-189.

21 Kloppel G, Maillet B: Pseudocysts in chronic pancreatitis: A morphological analysis of 57 resection specimens and 9 autopsy pancreata. Pancreas 1991;6:266-267.

22 Warshaw AL, Rattner DW: Timing of surgical drainage for pancreatic pseudocysts. Ann Surg 1985;202:720-724.

23 Bernades P, Belghiti J, Place S, Knezevitch Y, Fekete F: Histoire naturelle des collections liquidiennes au cours de la pancréatite chroniques. Gastroenterol Clin Biol 1985;9:2A.

24 Staub JL, Le Genissel H, Sarles H: Etude de la séméiologie et des résultats du traitement chirurgical de 103 cas de pancréatitis chroniques compliquées de kystes ou de pseudokystes. Gastroenterol Clin Biol 1981;5:433-439.

25 Usatoff V, Brancatisano R, Williamson RCN Operative treatment of pseudocysts in patients with chronic pancreatitis. Br J Surg 2000;87: 1494-1499.

26 Barthet M, Bugallo M, Moreira LS, Bastid C, Sastre B, Sahel J: Traitements des pseudokystes de pancréatique aiguë. Etude rétrospective de 45 patients. Gastroenterol Clin Biol 1992;16: 853-859.

27 Callery MP, Meyers WC: Surgical treatment of pseudocysts after acute pancreatitis; in Beger HG, Warshaw A, Carr-Locke DL, Russel RCG, Büchler M, Neoptolemos JP, Saar M (eds): The Pancreas. Boston, Blackwell Scientific, 1998, pp 614-626.

28 Grace P, Williamson R: Modern management of pancreatic pseudocysts. Br J Surg 1993;80: 573-581.

29 Heider R, Meyer A, Galanko JA, Behrns K: Percutaneous drainage of pancreatic pseudocysts is associated with a higher failure rate than surgical treatment in unselected patients. Ann Surg 1999;229:781-789.
30 London NJM, Neoptolemos JP, Lavelle J, James D: Serial CT scanning in acute pancreatitis. Gut 1989;30:397-403.

31 Sahel J, Barthet MAPM: Pseudocysts; in Beger HG, Warshaw A, Carr-Locke DL, Russel RCG, Büchler M, Neoptolemos JP, Saar M (eds): The Pancreas. Boston, Blackwell Scientific, 1998, pp 748-753.

32 Lillemoe K, Yeo CJ: Management of complications of pancreatitis. Curr Probl Surg 1998;35: 3-98.

33 Walt AJ, Bouwman DL, Wear DW, Sachs RJ: The impact of technology on the management of pancreatic pseudocyst. Fifth annual Samuel Jason Mixter Lecture. Arch Surg 1990;125: 759-763.

34 Adams DB, Anderson MC: Changing concepts in the surgical management of pancreatic pseudocysts. Am Surg 1992;58:173-180.

35 Williams KJ, Fabian TC: Pancreatic pseudocyst: Recommendations for operative and nonoperative management. Am Surg 1992;58: 199-205.

36 Becker WF, Pratt HS, Ganji H: Pseudocysts of the pancreas. Surg Gynecol Obstet 1968;127: 74-77.

37 Lewandrowski KB, Southern JF, Pins MR: Cyst fluid analysis in the differential diagnosis of pancreatic cysts: A comparison of pseudocysts serous cystoadenomas, mucinous cystic neoplasms and mucinous cystoadenoma. Ann Surg 1993;217:41-47.

38 Steinberg WM, Gelfand R, Anderson K, Glenn J, Kurtzwman SH: Comparison of the sensitivity and specificity of the CA 19.9 and carcinoembryonic antigen assays in detecting cancer of the pancreas. Gastroenterology 1986;90: 343-349.

39 Lowenfels AB, Maisonneuve P, Cavallini G, Amman RW, Lankisch PG, Andersen JR, Dimagno EP, Andren-Sandberg A, Domellof L: Pancreatitis and the risk of pancreatic cancer. International Pancreatitis Study Group. N Engl J Med 1993;328:1433-1437.

40 Maisonneuve P, Lowenfels AB: Chronic pancreatitis and pancreatic cancer. Dig Dis 2002; 20:32-37.

41 Uomo G, Rabitti PG: Chronic pancreatitis: Relation to acute pancreatitis and pancreatic cancer. Ann Ital Chir 2000; 71:17-21.

42 Bradley EL, Clementents LJ, Gonzalez AC: The natural history of pancreatic pseudocysts: A unified concept of management. Am J Surg 1976; 184:734-737.

43 Gouyon B, Ruszniewski P, Zins M, Hammel P, Vilgrain V, Sauvanet A, Belghiti J, Bernades P: Predictive factors in outcome of pseudocysts complicating alcoholic chronic pancreatitis. Gut 1997;41:821-825.

44 Sanfey H, Aguilar M, Jones RS: Pseudocysts of the pancreas, a review of 97 cases. Am Surg 1994;60:661-668.

45 Nguyen BL, Thompson JS, Edney JA: Influence of aetiology of pancreatitis on the natural history of pancreatic pseudocysts. Am J Surg 1989;162:527-531.
46 Yeo CJ, Bastidas JA, Lynch-Nyahan A, Fishman EK, Zinner MJ, Cameron JL: The natura history of pancreatic pseudocysts documented by computed tomography. Surg Gynecol Obstet 1990;170:411-417.

47 Neoptolemos JP, Ghaneh P, Sutton R, Hartley M, Hughes M, Garvey CJ, Lombard M, Smart $\mathrm{H}$, Gilmore I: Integrated radiology for surgical resection in chronic pancreatitis; in Büchler MW, Friess H, Uhl W, Malfertheiner P (eds): Chronic Pancreatitis. Boston, Blackwell, 2002, pp 277-295.

48 Neoptolemos JP, Winslet M: Pancreatic ascites; in Beger $\mathrm{H}$, Büchler $\mathrm{M}$, Ditschuneit $\mathrm{H}$, Malfertheiner P (eds): Chronic Pancreatitis. Berlin, Springer, 1990, pp 268-279.

49 Vitale GC, Lawhon JC, Larson GM, Harrel DJ, Reed DNJ, MacLeod S: Endoscopic drainage of the pancreatic pseudocysts. Surgery 1999; 126:616-623

50 Vitas GJ, Sarr MG: Selected management of pancreatic pseudocysts: Operative versus expectant management. Surgery 1992;2:123130

51 D'Egidio A, Schein M: Pancreatic pseudocysts: A proposed classification and its management implications. Br J Surg 1991;78:981-984.

52 Nealon WH, Walser E: Main pancreatic ductal anatomy can direct choice of modality for treating pancreatic pseudocysts (surgery versus percutaneous drainage). Ann Surg 2002;235: 751-758.

53 Bonnard A, Lagauise P, Malbeiz S, Sauvant E, Lemaitre AI, Algrain Y: Mediastinal pancreatic pseudocyst in a child. A thoracoscopic approach. Surg Endosc 2001;15:760.

54 Mehler CI, Soyer P, Kardache M, Pelage JP, Boudiaf M, Abitol M, Hamzi L, Rymer R: Computed tomography of intrahepatic pancreatic pseudocysts. J Radiol 1998;79:751755

55 Mofreddj A, Cadrenel JF, Dautreaux M, Karerouni F, Hadj-Necer K, Deplaix P, Francois G, Danon O, Lukumbo S, Collot G, Levy P, Harry G: Pancreatic pseudocyst located in the liver: A case report and literature review. J Clin Gastroenterol 2000;30:81-83.

56 Khawaja FI, Goldman LP: Endoscopic drainage of a pancreatic pseudocyst-gastric fistula. Gastrointest Endosc 1983;29:171.

57 Kozarek RA, Brakyo CM, Harlan J, Sanowski RA, Cintora I, Kovac A: Endoscopic drainage of pancreatic pseudocysts. Gastrointest Endosc 1985;31:322-328.

58 Beckingham IJ, Krige JEJ, Bornman PC, Terblanche J: Endoscopic management of pancreatic pseudocysts. Br J Surg 1997;84:16381645.

59 Chak A: Endosonographic-guided therapy of pancreatic pseudocysts. Gastrointest Endosc 2000;52:23-27.

60 Cooperman A: An overview of pancreatic pseudocysts. The emperor's new clothes revisited. Surg Clin North Am 2001;81:391-397.

61 Cremer M, Deviere J, Baize M: New device for endoscopic cystoenterostomy. Endoscopy 1990;22:76-77. 
62 Gerolami R, Giovannini M, Laugier R: Endoscopic drainage of pancreatic pseudocysts guided by endosonography. Endoscopy 1997; 29:106-108.

63 Sahel J, Bastid C, Pellat P, Schurgers P, Sarles $\mathrm{H}$ : Endoscopic cystoduodenostomy of cysts of chronic calcifying pancreatitis. Report of 20 cases. Pancreas 1987;2:447-453.

64 Smits ME, Rauws EA, Tygat GN, Huibregtse $\mathrm{K}$ : The efficacy of endoscopic treatment of pancreatic pseudocysts. Gastrointest Endosc 1995; 42:202-207.

65 Vidyarthi G, Steinberg S: Endoscopic management of pancreatic pseudocysts. Surg Clin North Am 2001;81:405-410.

66 Barth M, Sahel J, Bodiou-Bertie C: Endoscopic transpapillary drainage of pancreatic pseudocysts. Gastrointest Endosc 1995;42:208-213.

67 Binmoeller KF, Seifert H, Walter A, Soehendra $\mathrm{N}$ : Transpapillary and transmural drainage of pancreatic pseudocysts. Gastrointest Endosc 1995;42:219-224.

68 Catalano M, Geenan J, Schmalz M: Treatment of pancreatic pseudocysts with ductal communication by transpapillary pancreatic duct endoprosthesis. Gastrointest Endosc 1995;42: 214-218.

69 Kozarek RA, Ball TJ, Patterson DJ, Freeny PC, Ryan JA, Traverso LW: Endoscopic transpapillary therapy for disrupted pancreatic duct and peripancreatic fluid collections. Gastroenterology 1991;100:1362-1370.

70 Baron TH, Harewood GC, Morgan DE, Yates MR: Outcome differences after endoscopic drainage of pancreatic necrosis, acute pancreatic pseudocysts, and chronic pancreatic pseudocysts. Gastrointest Endosc 2002;56:7-17.

71 Beckingham IJ, Krige JE, Bornman PC, Terblanche J: Long-term outcome of endoscopic drainage of pancreatic pseudocysts. Am J Gastroenterol 1999;94:71-74.

72 Bejanin H, Liguory C, Ink O: Endoscopic drainage of pseudocysts of the pancreas. Study of 26 cases. Gastroenterol Clin Biol 1993;17: 804-810.

73 Cremer M, Deviere J, Engelholm L: Endoscopic management of cysts and pseudocysts in chronic pancreatitis: Long-term follow-up after 7 years of experience. Gastrointest Endosc 1989;35:1-9.

74 Deviere J, Bueso H, Baize M, Azar C, Love J, Moreno E, Cremer M: Complete disruption of the main pancreatic duct: Endoscopic management. Gastrointest Endosc 1995;42:445-451.

75 Dohmoto M, Rupp KD: Endoscopic management of pancreatic pseudocysts. Diagn Ther Endosc 1994;1:29-35.
76 Funnell IC, Bornmann Pc, Krige JE, Beningfield SJ, Terblanche J: Endoscopic drainage of traumatic pseudocyst. Br J Surg 1994;81:879881

77 Giovannini M, Pesenti C, Rolland AL, Moutardier V, Delpero JR: Endoscopic ultrasoundguided drainage of pancreatic pseudocysts or pancreatic abscesses using a therapeutic echo endoscope. Endoscopy 2001;33:473-477.

78 Inui K, Yoshino J, Okushima K, Miyoshi H, Nakamura Y, Watanabe S, Takashima T, Nakazawa S, Hattori T: EUS-guided one-step drainage of pancreatic pseudocysts: Experience in 3 patients. Gastrointest Endosc 2001;54:8789.

79 Libera ED, Siqueira ES, Morais M, Rohr MR, Brant CQ, Ardengh JC, Ferrari AP: Pancreatic pseudocysts transpapillary and transmural drainage. HPB Surg 2000;11:333-338.

80 Norton ID, Clain JE, Wiersema MJ, Dimagno EP, Petersen BT, Gostout CJ: Utility of endoscopic ultrasonography in endoscopic drainage of pancreatic pseudocysts in selected patients. Mayo Clin Proc 2001;76:794-798.

81 Sharma SS, Bhargawa N, Govil A: Endoscopic management of pancreatic pseudocyst: A longterm follow-up. Endoscopy 2002;34:203-207.

82 Vilmann P, Hancke S, Pless T, et al: One step endosonography-guided drainage of a pancreatic pseudocyst: A new technique of stent delivery through the echo endoscope. Endoscopy $1998 ; 30: 730-733$

83 White SA, Sutton CD, Berry DP, Chillistone D, Rees Y, Dennison AR: Experience of combined endoscopic percutaneous stenting with ultrasound guidance for drainage of pancreatic pseudocysts. Ann R Coll Surg Engl 2000;82: 11-15.

84 Sacorafas GH, Sarr MG, Farley D, Farnell MB: The significance of sinistral portal hypertension complicating chronic pancreatitis. Am J Surg 2000;179:129-133.

85 Jedlicka R: Eine Nervenoperationsmethode der Pancreaszysten (Pancreato-gastrostomie). Zentralb Chir 1923;50:132.

86 Bodker A, Kjaergaard J, Schmidt A, Tilma A: Pancreatic pseudocysts. A follow-up study. Ann Surg 1981;194:80-84.

87 Bumpers HL, Bradley EL: Treatment of pancreatic pseudocysts; in Howard J, Idezuki Y, Ihse I, Prinz R (eds): Surgical Disease of the Pancreas. Baltimore, Williams \& Wilkins, 1998, pp 423-432.

88 Cooperman A: Surgical treatment of pancreatic pseudocysts. Surg Clin North Am 2001;81: 411-419.

89 Falconi M, Casetti L, Salvia R, Sartori N, Bettini R, Mascetta G, Bassi C: Pederzoli P: Pancreatic head mass, how can we treat it? Chronic pancreatitis: Surgical treatment. JOP 2000;1(3 suppl):154-161.
90 Kiviluoto T, Kivisaari L, Kivilaakso E, Lempinem M: Pseudocysts in chronic pancreatitis. Surgical results in 102 consecutive patients. Arch Surg 1989;124:240-243.

91 Moran B, Rew DA, Johnson CD: Pancreatic pseudocyst should be treated by surgical drainage. Ann R Coll Engl 1994;76:54-58.

92 Parks RW, Tzovaras G, Diamond T, Rowlands BJ: Management of pancreatic pseudocysts. Ann R Coll Surg Engl 2000;82:383387.

93 Pedrazzoli S, Sperti C, Pasquali C: Pancreatic head resection for non-inflammatory benign lesions of the head of the pancreas. Pancreas 2001;23:309-315.

94 Altimari A, Aranha GV, Greenlee HB, Prinz RA: Results of cystoduodenostomy for treatment of pancreatic pseudocysts. Am Surg 1986;52:439-441.

95 Newell KA, Liu T, Arancha GV, Prinz RA: Are cystogastrostomy and cystoduodenostomy equivalent operations for pancreatic pseudocysts? Surgery 1990;108:635-639.

96 Sankaran S, Walt AJ: The natural and unnatural history of pancreatic pseudocysts. Br J Surg 1975;62:37-44.

97 Spivack H, Galloway JR, Amerson JR, Fink AS, Branum GD, Redvanly RD, Richardson WS, Mauren SJ, Waring JP, Hunter JG: Management of pancreatic pseudocysts. J Am Coll Surg 1998;186:507-511.

98 Cho HG, Min HY, Jang DS, Shin YW, Kwon KS, Kim SH, Kim MY, Kim KR: Two cases of chronic pancreatitis with pseudocyst complicated by obstructive jaundice. Yonsei Med J 2000;41:522-527.

99 Warshaw AL, Rattner DW: Facts and fallacies of common bile duct obstruction by pancreatic pseudocysts. Ann Surg 1980;192:3337.

100 Boerna A, van Gulik TM, Obertop H, Gouma DJ: Internal drainage of infected pancreatic pseudocyst: Safe or sorry? Dig Surg 1999;16: 501-505.

101 Beger HG, Schlosser W, Friess HM, Büchler MW: Duodenum-preserving head resection in chronic pancreatitis changes the natural course of the disease: A single-center experience. Ann Surg 1999;230:512-519.

102 Frey CF, Smith GJ: Description and rationale of a new operation for chronic pancreatitis. Pancreas 1987;2:701-707.

103 Heider R, Berns KE: Pancreatic pseudocys complicated by splenic parenchymal involvement: Results of operative and percutaneous management. Pancreas 2001;23:20-25. 